\title{
The earth sciences in the scientific letters of Giovanni Capellini
}

\author{
Marco Caciagli and Graziano Ferrari \\ Istituto Nazionale di Geofisica e Vulcanologia, Bologna, Italy
}

\begin{abstract}
Giovanni Capellini (1833-1922) was one of the leading representatives of the Italian and international scientific community from the mid-19th century until 1922, the year of his death.

Professor of Geology at the University of Bologna from 1860, geologist, palaeontologist and archaeologist, in 1871 he organised, straight after the unification of Italy, the 5th International Congress in Archaeology and Prehistoric Anthropology, first in Italy, and in 1881 brought to Bologna, for the first time ever in Italy, the 2nd International Geological Congress. His studies and publications strongly influenced the geological thinking of his times.

At the Archiginnasio Library in Bologna there are as many as 30,000 documents from his scientific letters (The Capellini Archive), the result of an intense correspondence he had with geologists, seismologists, astronomers and meteorologists, but also with people from the world of culture and politics. The letters relating to the earth sciences, from scientific but also political point of view, are the majority. The archive includes letters from more then 4,300 senders, of which at least 25\% foreign ones incuding Charles Lyell (geologist), Emmanuel Friedlaender (volcanologist), Philip Eduard De Verneuil (naturalist), Henry James Johnston Lavis (volcanologist).
\end{abstract}

Key words Giovanni Capellini - history of earth sciences, scientific letters - 2nd International Geological Congress, letters in earth sciences project, Archiginnasio Library in Bologna

\section{Introduction}

Scientific letters have an important role in the Earth sciences, both from a historical-cultural and scientific point of view. They allow us to reconstruct the history, the evolution of the different disciplines in the frame of this broad field of science (geology, geophysics, meteorology, astronomy and so on) and also biographies of famous «players» in the history of this sci-

Mailing address: Dr. Marco Caciagli, Istituto Nazionale di Geofisica e Vulcanologia (INGV), Sezione di Bologna, Via D. Creti 12, 40128 Bologna, Italy; e-mail: caciagli@bo.ingv.it ence. Not seldom, in these particular documents, we can find information and data still useful to better define some historical extreme natural events (Ferrari, 2002). Some scientists are distinguished for their eclecticism in the different fields of earth sciences and long-standing activity. Their letters are usually like a rich «mine» often unexplored with historical evidence of great scientific interest, as well as from cultural and historical points of view.

Giovanni Capellini was one of them. An eminent geologist, with a long presence in the scientific community (60 years) and in political relations, in his letters he discussed with people from the science world, from politics and from the cultural community in general. The «Capellini Archive» (over 30,000 letters) is also a great opportunity to know aspects of custum and history in the period from 1860 to 1920 . Therefore, a short biography of G. Capellini will be useful to understanding the importance and complexity of his largely unexplored letters collection. 


\section{A short biography of Giovanni Capellini (1833-1922)}

Giovanni Capellini (fig. 1) was born to a humble family in La Spezia (Italy) on 23rd August 1833 .

He began to study theology in the seminar of Pontremoli and during this time he opened a physics laboratory visited, in 1853 , by the «Prince of Piedmont». At that time he became friends with Umberto di Savoia, future King of Italy, a friendship that, of course, proved very useful during his life.

He studied at his home town and was later forced to make great sacrifices in order to graduate in geology at Pisa in 1858 (Capellini, 1914). At the same time, during the universitary period, he was a correspondent member of the Naturalistic Society of Halle (Naturforschende Gesellschaft zu Halle) (Vai, 2003a). The scientific context of Pisa was a great learning experience for the young Capellini. The University of Pisa was, at that time, one of the most important sites for the development of the Geological Sciences in Italy (Corsi, 2001a). It was the decade immediately after the construction of the Pisa school of geology born out of the meeting, or rather the clash, between the previous naturalist tradition of Paolo Savi (1823-1871) and Giuseppe Meneghini (1811-1889) and the «Neapolitan» Leopoldo Pilla (1805-1848). Savi and Meneghini were both geologist naturalist much esteemed in the European context and Pilla, called upon by the Great Duke of Tuscany to deal with the newly founded Chair of Geology at the University of Pisa, is considered by the historians of Earth Sciences to be one of the founders of Regional Geology.

After his degree, Capellini intensified his excursions surveying, in particular in Liguria and Tuscany regions and, during this period, made a strong friendship with Lorenzo Pareto (18001865), another important figure in the history of Italian geology. He went to France as well as Switzerland, Germany and England, where he met same of the great men of science of that time: R. Owen, J. Gwyn Jeffreys and C. Lyell.

He started teaching in 1860 in Genoa and then, in the same year, moved to the Chair of Geology of the University of Bologna where he remained for the test of his life.

We could consider Capellini a «son of the Pisan school». The scientific approach of this school was the same as that of Constant Prévost and Charles Lyell (Corsi 1998; 2001a,b; 2003) both strong objectors of the «Catastrophism», theory dominant during the 19th century. The vacant position in Bologna university, assigned to him rather than the very Catholic Giuseppe Bianconi (Tabanelli, 1989), in addition to recognizing his merits, was a clear political signal of the Royal House to the new Kingdom of Italy; a modernization in a positivistic sense of the national leadership, starting from its schools and universities (Vai, 2003a,b).

During this period Capellini's activities became fervent and eclectic both in Italy and abroad. In 1861 he was involved in the organization of 43rd Session of Helvetic Society of Natural Sciences in Lausanne. Since the same year was a member of the «Giunta Consultiva» for the elaboration of a Geological Map of Italy; Lorenzo Pareto was the President of this commission and Capellini made final report (Corsi, 2003). On that occasion, he established a strong friendship with Quintino Sella (18271884), already a famous geologist and then Italian Financial Minister.

Encouraged by famous geologists like C. Lyell, Ph. E. De Verneuil, R. I. Murchison and J. Marcou, in 1863 Capellini went to America. After this trip he published a report and a book of memoirs (Capellini, 1864; 1867), numerous papers, but, in particular, during his visit he made important relations with the owners of the main paleontological collections. There, he met scientists like the Swiss L. Agassiz, one of the most famous European palaeontologists who had moved to the United States, J.W. Dawson, J. Hall, C.H. Hitchcock and J.S. Newberry, all persons that will be among the founding members of the International Geological Congress.

In 1865 he was president and convener of the 2nd Congress of Italian Society of Natural Science held in La Spezia. The previous edition had been chaired by Quintino Sella and during that edition, after a previous consultation with the French paleontologist Edouard Armand Lartet and Gabriele De Mortillet, Capellini was main promoter of the proposal for the organiza- 


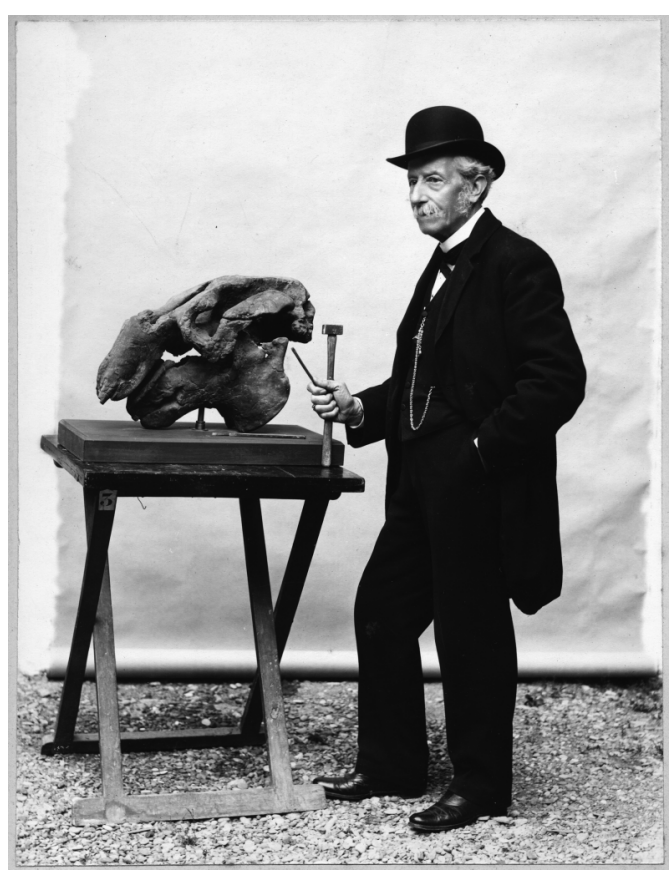

Fig. 1. Giovanni Capellini at work in the museum (Archives of the Capellini Museum. We wish to thank the Curator of the Museum, Prof. Gian Battista Vai, for having made this photograph available to us).

tion of the first International Congress of Archaeology and Prehistoric Anthropology then held in 1866, in Neuchâtel, where P.E. Desor was president. The next session in 1867 , on the occasion of the Universal Exhibition in Paris, was to be chaired by E.A. Lartet (later because of his indisposition, replaced by Longpérier) with the Secretary-General G. De Mortillet, true «soul» of the Congress. The 3rd edition, held in London and chaired by J. Lubbock, risked «failure» in the number of participants due to the willingness to use English for the conference communications (Capellini, 1914).

In 1869, during the 4th edition of this congress with V. Schmidt general secretary, as charter member of the Congress he was appointed, both with P.E. Desor, Honorary Vice President and charged to assume the organization of the 5th International Congress of Archaeology and Prehistorical Anthropology in
Bologna, the first in Italy, held in 1871 with the political contribution of Marco Minghetti, Minister of Agriculture and Trade and soon after Prime Minister. Capellini set up as exhibition space for that congress four rooms of the exmedical clinics of Bologna university that later became the core of the future Geological and Paleontological Museum.

He was appointed President of the sixth edition held in Brussels in 1872. On that occasion he «fought» for the use of French as the language for the international congress in opposition to the English scientific community (Capellini, 1914; Wiell, 1999; Vai, 2003a).

Capellini had significant roles in all subsequent editions in which he participated (Capellini, 1905).

The use of French in the international field was strongly felt by Capellini. He considered the abandonment of that language as «the end of the congress» (Capellini, 1914 p. 189) and provocatively he signed some of his work as Jean Capellini (Capellini, 1871).

In 1881, he organised, in Bologna, the 2nd International Geological Congress (IGC). Certainly due to his credit in the international scientific context, experience in organizing conferences but, also, for the primary role he had during the first edition held in Paris in 1878 (Vai 2003a). During this edition of IGC he founded, with Quintino Sella, Felice Giordano, Giuseppe Meneghini and F. Molon, the Italian Geological Society (fig. 2) in order to «contribute to the progress of Geology with publications, encouragement and the facilitating of the relations between the partners» (S.G.I, 1882). The evening of 28th September 1881, in a hall of the «Archiginnasio Library» of Bologna, he chaired the first founding meeting and was a member, together with Meneghini, Sella, De Stefani and Taramelli, of the commission whose task it was to study and put forward the statute of the new Society in the shortest possible time.

During that Congress, on September 26th the official inauguration of the Geological and Paleontological Museum took place, subsequently dedicated to Capellini.

Called upon to be a member, he contributed to the scientific life of nearly all the academies of the world and he participated in all the geo- 
logical, paleontological and anthropological congresses abroad, often as the only Italian delegate.

He had in the meantime become Senator of the Kingdom of Italy and an important member of the Royal Geological Committee.

From 1861, he actively contributed to the founding of the Geological Office of the Royal Corps of the Mines chaired by his friend Felice Giordano and to the planning and elaboration of the Geological Map of Italy.

He was also the Chancellor of Bologna University (1874-76, 1885-88 and 1894-95).

In 1888, during his rectorate, he organized the solemn celebration of the eighth century of the University of Bologna. On that occasion, he invited delegations from the main universities and international academies as well as Royal Houses from numerous nations (Capellini, 1914). The museum came to house even more collections and exhibits from around the world thanks to donations made by means of its director.

As the same time, Capellini was personally committed in public life, even in the debate on the urbanistic plan of his host city (Musiani, 2004). He was also among the first to deal with the History of Science, a new discipline often flouted by his contemporaries, dedicating himself actively to research and the preservation of manuscripts and instruments utilised by his predecessors.

In the last few years of his life he dedicated all of his time to reordering his research, amongst which his valuable correspondence. Capellini well understood the importance and the wealth that his letters represented and it is thanks to this awareness that most of it has come down to us.

On 28th May 1922 Giovanni Capellini died in Bologna after a short illness.

\section{Correspondence}

The Archiginnasio Library in Bologna preserves as many as 30,000 documents from Capellini's scientific letters (The Capellini Archive), the result of an intense correspondence he undertook with geologists, seismologists, astronomers and meteorologists, but also

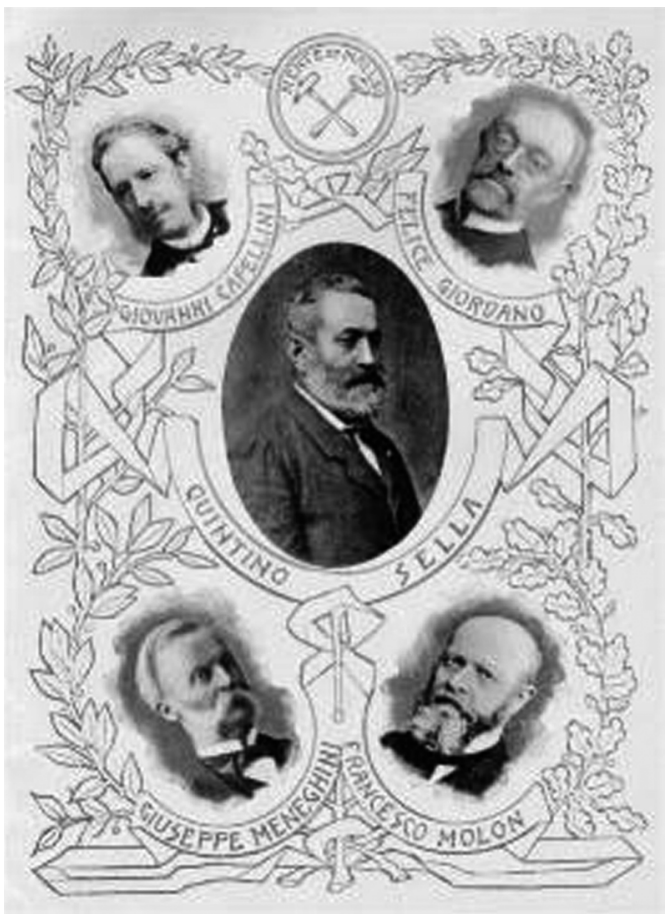

Fig. 2. Image taken from the Volume 1 S.G.I. Bulletin (1882) depicting the Perpetual Partners of the Italian Geological Society. From left up to right down G. Capellini, F. Giordano, Q. Sella, G. Meneghini and F. Molon (from http://www.socgeol.it).

with people from the world of culture and politics (Sorbelli, 1928).

This extraordinary collection of letters that embraces over 60 years of history of the geological sciences was organised and arranged by Capellini himself, well aware of the importance that this type of documentation could have for the history of science.

In the last few years of his life he dedicated his time to rearranging his documentary and bibliographic heritage: besides the many letters Capellini also possessed a very rich collection of volumes and geological pamphlets in general, which he donated to the Institute of Geology of Bologna University.

This short account on such a vast archive is an attempt to survey the extraordinary importance of these documentary assets which, 


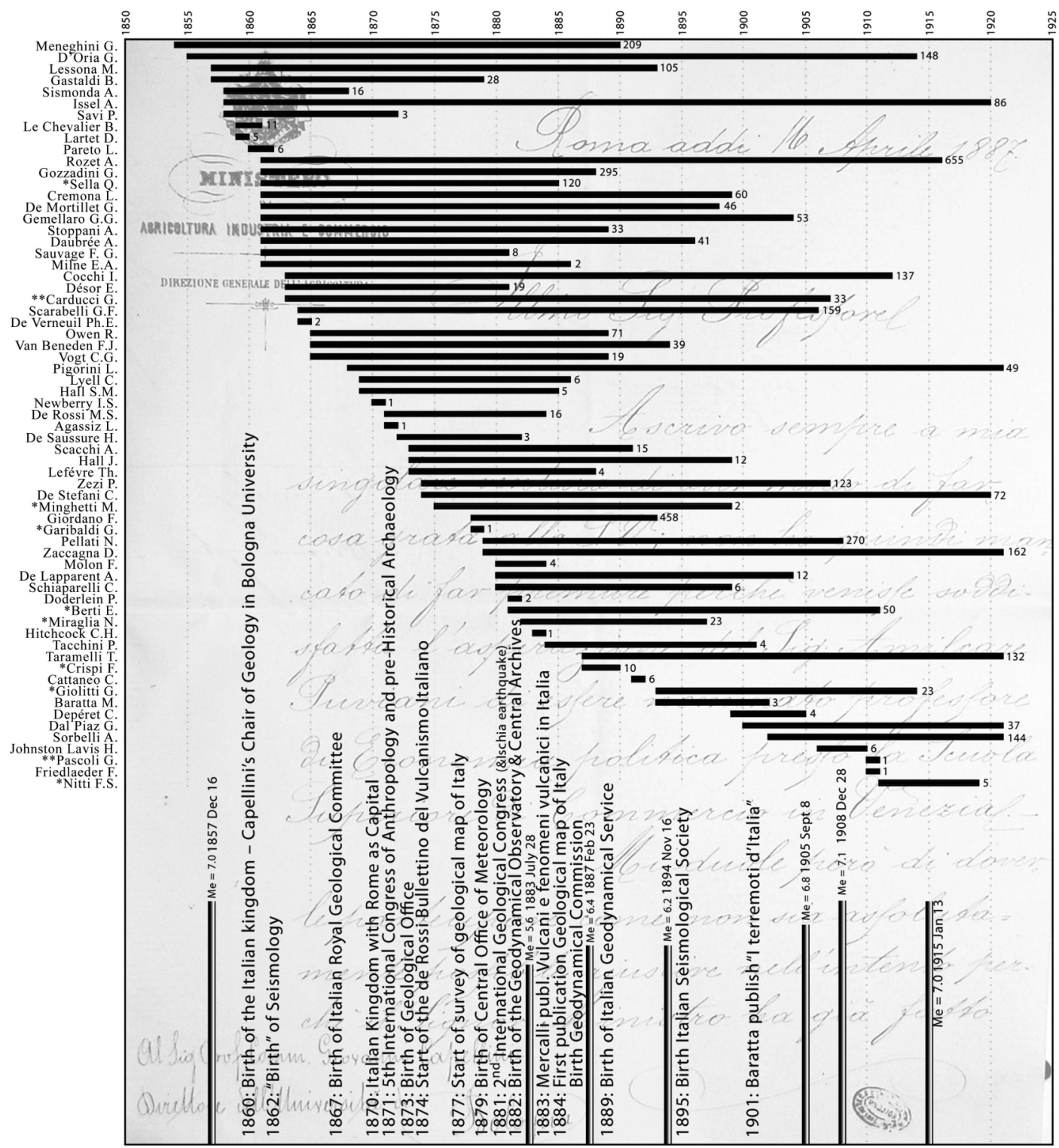

Fig. 3. Graphic representation of the period of the correspondence and the number of letters exchanged between G. Capellini and a select number of characters chosen as representatives of the scientific disciplines, the politics $(*)$ and culture $(* *)$ of that times. Also indicated is the chronology of the scientific, political and cultural events that characterised the era in which Capellini lived and the main seismic events occurring in the time-span considered. 


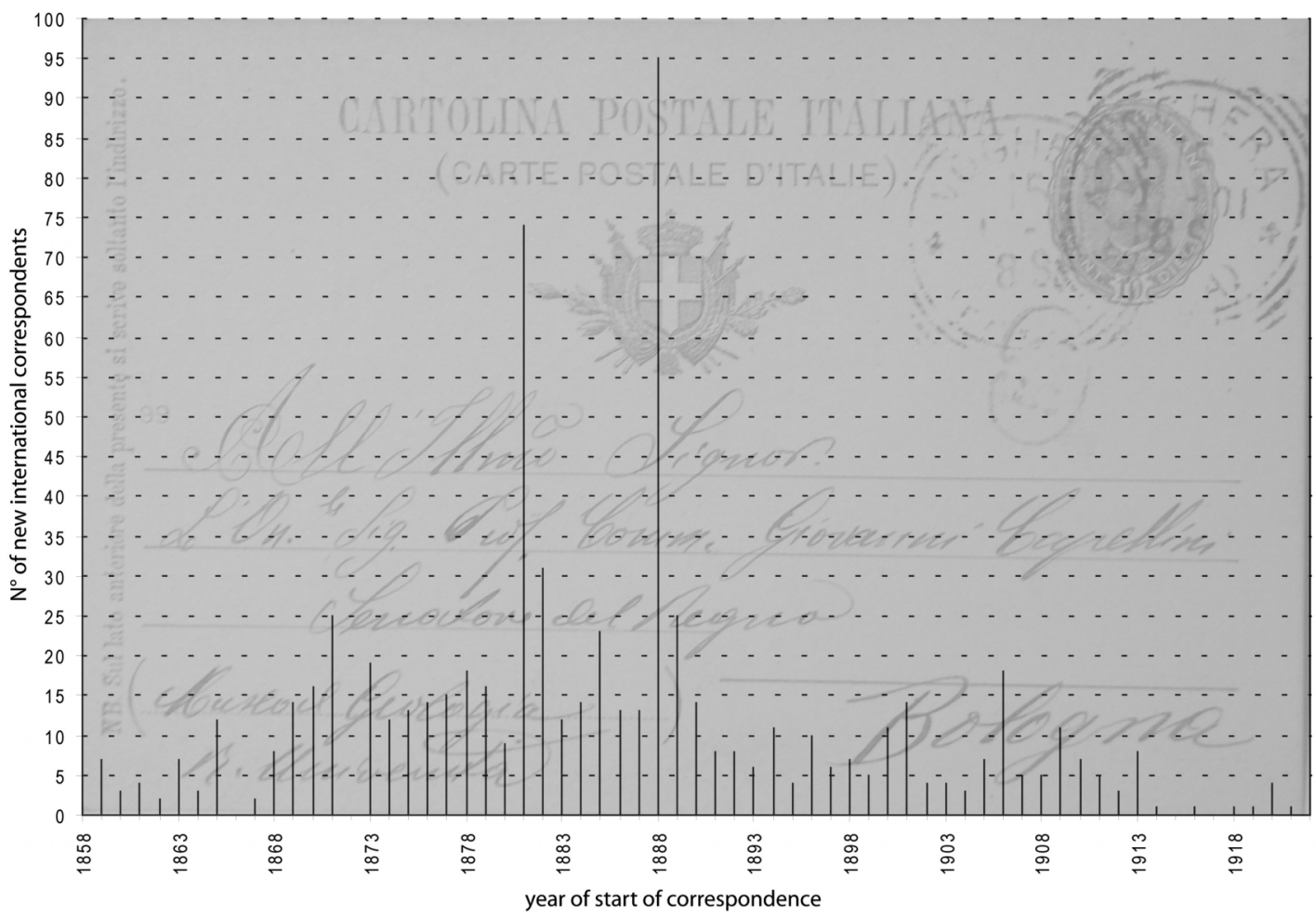

Fig. 4. Chart of the number of new international correspondents correlated with the start of the correspondence.

thanks to their sheer size and value as testimonies, provide us with a unique picture of the scientific debate that took place within the disciplinary sectors explored by the great scholars like Capellini, together with the political and social history of Italy between the 19th and 20th centuries.

In the list of correspondents in the «The Capellini Archive» (Sorbelli, 1928) there stands out Capellini's strong relationship with F. Giordano (458 letters from 1878 to 1892), Nicola Pellati (270 letters from 1879 to 1907), Giuseppe Meneghini (209 letters from 1854 to 1989), Torquato Taramelli (132 letters from 1887 to 1920) and Quintino Sella (120 letters from 1861 to 1984). He had similar relationships with Giovanni Gozzandini, Domenico Zaccagna, Igino Cocchi, Pietro Zezi, Giovanni Omboni, Michele Lessona, Antonio Stoppani and Luigi Pigorini to mention just some of the main scientists of the Italian community of the second half of the 19th century. Scrolling the names list it is possible to read, among others, the names of Giosuè Carducci, Giovanni Pascoli, Giovanni Giolitti, Nicola Miraglia, Francesco Crispi, Francesco Saverio Nitti, Giuseppe Garibaldi, in other words, leading exponents of politics and culture of Italy.

The chart in fig. 3, relates the time period to the number of letters posted for a selection of the main senders. It should be noted that G. Capellini carried out his activities in a period of important political and scientific events.

In the international setting Capellini's correspondence demonstrates the prestige acquired in the scientific debate, in an era when the fledgling evolutionary theory clashes with the consolidated diluvianistic theory (Vai, 2003b). 
Inside the «Capellini Archive» we can find the names of Ch. Lyell, Ph. E. De Verneuil, J. Hall, H. De Saussure, Sterry Hunt I., C.H. Hitchcock, J.S. Newberry, L. Agassiz, P.J. Desor, E. Friedlaender, R.W. Bunsen, H.J. Johnston Lavis, M. Yokoyama and many others.

In terms of rate of correspondence, the relationships with Artur Issel (86 letters from 1858 to 1919), Richard Owen (71 letters from 1865 to 1888), Gabriel August Daubrée (41 letters from 1861 to 1895), Gabriel De Mortillet (46 letters from 1861 to 1895) and then P.J. Van Beneden, A. Geikie, E. Von Mojsisovics and A. De Lapparent.

Figure 4 shows the number of new international correspondents correlated with the start of the correspondence. Note that the increase in the number of new correspondents is particularly evident at the Congress of 1871 and 1881 with another significant peak in 1888 , on occasion of the eighth centenary commemoration of Bologna University. The chart also shows that this kind of correspondence was began before Capellini had a considerable role in the Italian scientific community, highlighting the fervent activity of his youth.

The number of new correspondents tend to grow over time until 1890, in proportion to the international prestige gained. Moreover, new international correspondents still report in 1920 , reflecting the continued scientific work until the last years of Capellini's life.

Precisely for his recognised political and social status, besides his scientific position, he was involved, mainly by Q. Sella and F. Giordano, in the drafting of the Acts of Parliament relating to the establishment of the Royal Geological Committee (1867) and the Geological Office of the Royal Mining Corps (1873), institutions mainly founded to draw up the Geological Map of Italy and to offer services and opinions for the development of great public works.

From a preliminary reading of the letters exchanged with Felice Giordano, the difficulties encountered in the creation of the geological map become apparent.

Its first sheets were only published in 1884 (fig. 5), 17 years after the founding of the Geological Committee, and 23 years after the first meeting of the «Giunta Consultiva» recalled above (for details about the history of Italian Geological Map see Corsi 2003). In particular, Giordano, director of the Italian Geological Map project from 1876, complains in a letter dated 31st March 1883,

«[...] with the Geographical Institute, that is with the horrible maps that it has published, we are at the stage where today we cannot publish any presentable Geological Map, unless we have the topographical map also made specially for us. It is an issue that our Committee will have to deal with, indeed the Geographical Institute itself is already aware of the reforms necessary to the said Topographical Maps.»

These of observations were also officially expressed in the «Illustrative Notes» (fig. 5) that followed the publications of the Geological Map. The economic importance linked to the mineral extractions meant that priority was given to the publication of the sheets relating to the Sicily region over a time-span going from 1884 and 1886.

Another problem is linked to the negligence of the political world that should have legislated in this regard. In another letter written by Giordano dated 19th May 1883 we read:

«[...] Here things are as they usually are, with a minister like Berti [minister of Agriculture, Industry and Trade] who never finds the time to do what he wants to do, and who loses and loses again all the notes that are prepared for him. No more has been said about the Law on the Geological Map, although he was given the notes». (fig. 6a).

Again from this correspondence, but not only with Giordano, the international prestige given to Capellini becomes apparent. He was involved in the realisation of the Geological Map of Europe, by means of which mediation was sought to resolve the technical and scientific controversies raging between Italian and European geologists.

The role he holds in the Italian sphere was beyond doubt. He was the founder, during the 2nd International Geological Congress, of the Italian Geological Society which he had organised. Moreover, he was an influential member of the National Academy of the Lincei (the most important academy of those times) shortly before relaunched by his friend Sella and on 


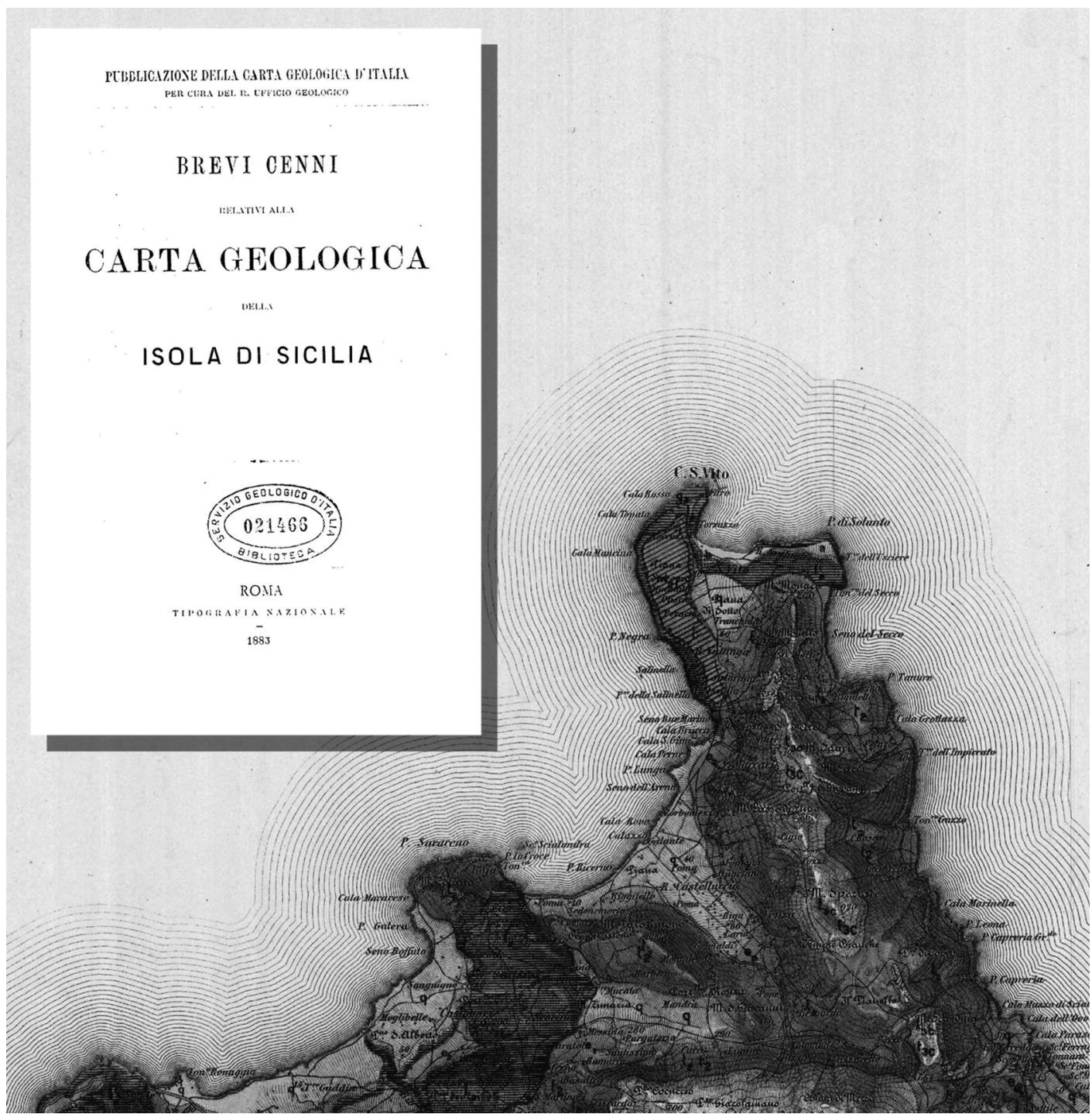

Fig. 5. Extract of one of the first geological maps of Italy published in 1884 (Sheet n. 248 Trapani - Island of Sicily), drafted by the Royal Geological Office. In the box the main page of the «Illustrative Notes».

good terms with the Royal House. He was a figure whose advice was heeded for the «Royal Prizes» awarded for the various disciplines and in case of the election of the managerial bodies of the various academies and institutions he was involved in. Suffice it to read in this regard the letter of thanks by T. Taramelli dated 20th December 1881, where we can read:

«Illustrious colleague and friend, I know how much you have contributed to my being awarded to Royal Prize of the Academy [...] I and my children 

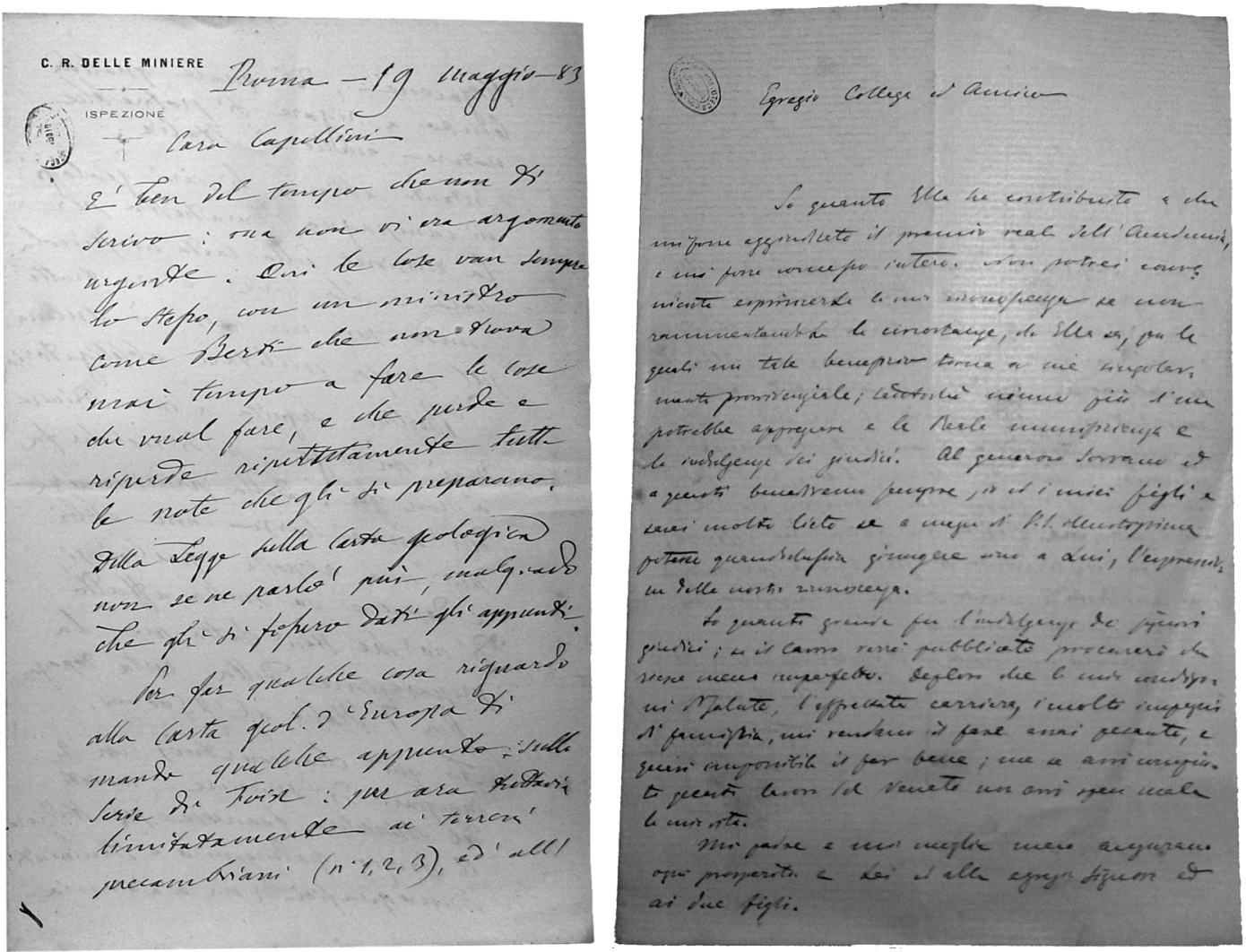

Fig. 6a-b. a) Extract of the letter posted to Giovanni Capellini by Felice Giordano dated 19th May 1883 on the problems about the publication of the Geological Map of Italy. Note that just one year later the first sheets of the Map would be published (translation in the text). b) Letter of thanks posted to Giovanni Capellini by Torquato Taramelli dated 20th December 1881 (translation in the text).

will forever bless the Sovereign and the judges, and I would be very glad if you could pass on to Him (The King) the expression of our thanks and recognition. [...]» (fig. 6b).

Numerous scholars of the history of seismology (not just Italian) exchanged correspondence with him. His long period of office in the scientific, political and cultural world allowed him to meet at least three generations of seismologists. We shall briefly sum up the biographic profiles of some of these correspondents to fully appreciate the importance of the scholar and his massive letter bank.

\section{Conclusions}

Given the sheer span of time involved, along with the prestige, the variety and the number of his correspondents, the letters of the Giovanni Capellini archive represent an important as well as privileged «observatory» of the history of the earth sciences both in Italy and Europe, with particular regard to seismology and volcanology. Within the scope of the project called Letters in Earth Sciences (INGV-SGA) (http://storing.ingv.it/letters) we have started cataloguing and digital scanning of the letters with the greatest scientific appeal. 


\section{Appendix}

1. Felice Giordano (Turin 1825-Vallombrosa 1892) concluded his engineering studies in 1847 , from the same year until 1852 he studied at the school of the Mines of Paris together with his friend Quintino Sella. He directed the Mines Service in Sardinia from 1852 to 1859 . He returned to Turin to manage the Mining Corps and in 1870 was appointed Inspector General.

His role was of fundamental importance for all the various sectors of the Earth Sciences that were developing and taking shape in that period. Besides his previously mentioned role in the organisation of a geological service in the Kingdom of Italy and in the foundation of the Italian Geological Society, Giordano had a crucial role in the organisation of the first nucleus of a geodynamic service in Italy, handed over to Michele Stefano De Rossi. He was indeed one of the first and most active supporters of the need to establish a geodynamic service, «institutionalising» the «private» service already set up back in 1874 by De Rossi himself.

2. Michele Stefano De Rossi (Rome, 1834-Rocca di Papa, 1898) is considered to be one of the pioneers of seismology. The Vesuvian eruption of May 1872, the Lazio earthquakes of January 1873 and, above all, those of 12 March in Camerino and 29 June in Belluno persuaded him to collect a series of news accounts and observations which were published in 1874 in a memoir (De Rossi, 1874) which presents his first version of a scale of intensity. De Rossi was sure that subsurface phenomena, like destructive earthquakes and the main volcanic eruptions, are not the maxima of a continuous activity, which on the contrary usually is characterized by weak and often imperceptible manifestations. As a consequence De Rossi thought that only by systematic study of the whole process of this activity, made with suitable instruments and continuous observation, would chronological and topographical statistical examination of each phenomenon be possible, even minor ones such as variations in the well-waters level and temperatures of springs etc. But only an organisation similar to the meteorological one, which was characterised by an extensive network of observatories, could make possible the systematic collection of data. Since 1873 De Rossi himself began to organise this network; the following year he started publication of the Bullettino del Vulcanismo Italiano (Bulletin of the Italian Volcanism), as the main medium for diffusion of data, discussion of the results and promotion of the organisation. The bulletin was the first scientific review entirely devoted to earth sciences.

After the disastrous earthquake of Casamicciola, near Ischia, of 1881 following urgent appeals from Felice Giordano, the Geological Committee obtained from the Ministry for Agriculture and Trade the authorization to finance in part De Rossi's organization. The following year the Geodynamical Observatory and Central Archives were officially inaugurated and Rossi became its first director.

In 1883 another disastrous earthquake at Casamicciola the Geodynamical Committee was set up, of which De Rossi was a member. The committee decided to set up a geodynamical service for the whole country and planned the establishment of three first order observatories in Catania, Casamicciola and Rocca di Papa.

De Rossi was given the task to find a site and design buildings for the observatory of Rocca di Papa (near Rome); in 1889 , when the observatory was nearly ready, the geodynamical service was separated from the geodynamical committee to became a branch of the Central Office of Meteorology, and De Rossi was made director of the observatory of Rocca di Papa.

3. Quintino Sella (Mosso, 1827-Biella, 1884) graduated in Hydraulic Engineering in 1847. He was appointed apprentice engineer in the Royal Mining Corps, and was sent to Paris by the Ministry of the Interior, together with Felice Giordano, to do a three-year masters course at the Ecole des Mines. Thanks to his relations with $\mathrm{H}$. de Sernamont, professor of Mineralogy in Paris, and thanks to other study periods in Germany and England (1851-1852), Sella laid the foundations of his scientific career, especially based on crystallographic studies. Upon his return to Turin, Sella was appointed professor of Practical Geometry at the Technical Institute which, thanks to the interest he took, was soon afterwards transformed into a School of Application for Engineers (1859). In 1860 Sella was given the Chair of Mineralogy at the same School, but was forced to resign soon afterwards owing to his political commitments.

He was among the founders of two important Italian scientific and cultural institutions: in 1863, the Italian Alpine Club and in 1881, the Italian Geological Society. In 1884, for a few months before his death, Sella was the president of the Royal Geodynamic Commission, with the task of setting up a geodynamic service in Italy. An eminent statesman and economist, Sella was a minister in various governments of the Kingdom of Italy.

4. Luigi Palmieri (Faicchio, 1807-Valle di Pompei, 1896) was one of the most illustrious scholars of earth sciences in the second half of the 19th century, above all in the field of volcanology. Graduated in physics and math- 
ematics and afterwards in philosophy, in 1831 he opened a private school of philosophy and physics which enjoyed a huge success, attracting each year some 400 students.

Palmieri's first seismological studies date back to the 1850s. In 1851 he and the geologist Arcangelo Scacchi were members of a committee of the Accademia delle Scienze of Naples charged with the study of the Melfi earthquake. The survey resulted in the publication of a notable monograph. The following year Palmieri was authorised to study atmospheric electricity in the Vesuvian observatory, the first geodynamic observatory in the world.

In 1855 he was given another task by the Accademia delle Scienze, that of surveying together with Scacchi and Guarini the eruption of Vesuvius which had begun in May. It was probably during the onset of the eruption that Palmieri had the idea of making a seismograph. Observing the flow from the observatory, he realised that eruptive activity was accompanied by a series of seismic tremors, some of which were so weak that they could hardly be perceived by a careful observer. He therefore devised an electromagnetic seismograph expressly to register these tremors.

The importance of an advanced observing station with so good instrumentation was demonstrated during the eruption of 1872, when for the first time a volcanic phenomenon could be directly observed close to its origin.

5. Mario Baratta (Voghera, 1868-Casteggio, 1935) graduated in natural sciences in 1890 at the University of Pavia. Under the supervision of Torquato Taramelli, he worked at the Geodynamic Observatory of Ischia directed by Giulio Grablovitz. From 1892 to 1896 he was the extraordinary geodynamic assistant at the Central Office of Meteorology and Geodymnamics in Rome. Although Baratta's greater commitment to the seismological field was limited to the period 1890-1910, when he became professor of Geography at the University of Pavia in 1911, he frequently took a more incisive part in the scientific debates on the occasion of the most important Italian earthquakes of his times. One of the leading figures of Italian seismology between the 19th and 20th centuries, between 1890 and 1900 Baratta published over 50 works and monographic studies on earthquakes. Among his most important works is I terremoti d'Italia (Baratta, 1901), a study into the effects of the earthquake of the Messina Strait on 28th December 1908: la Catastrofe sismica calabro-messinese (Baratta, 1910).

\section{REFERENCES}

BARATTA, M. (1901): I terremoti d'Italia. Saggio di storia geografia e bibliografia sismica italiana (ristampa anastatica, Sala Bolognese1979), Torino, pp. 950.

BARATTA, M. (1910): La catastrofe sismica calabro messinese (28 dicembre 1908), Relazione alla Società Geografica Italiana, 2 voll., Roma, pp. 458 (ristampa anastatica, Sala Bolognese 1985).

CAPELlinI, G. (1864): Relazione di un viaggio scientifico fatto nel MDCCCLXIII nell'America Settentrionale, (Ed. Gamberini e Parmeggiani, Bologna), pp. 44.

CAPELlinI, G. (1867): Ricordi di un viaggio scientifico fatto nell'America Settentrionale nel MDCCCLXIII, (Tip. Giuseppe Vitali, Bologna), pp. 279.

CAPELlini, J.(G.) (1871): Carte Geologique des environs de Bologne et d'une partie de la vallee du Reno, (Bologna, Italy).

CAPELLINI, G. (1905): Apercu historique du congres international d'antropologie et d'archeologie prehistoriques, (Paris libr. C. Reinwald).

CAPEllini, G. (1914): Ricordi, (Bologna, Zanichelli), vol. 1, pp. 242; vol. 2, pp. 356.

CoRsI, P. (1998): Le scienze naturali in Italia prima e dopo l'Unità, in Ricerca e istituzioni scientifiche in Italia, edited by R. SimiLI, (Bari, Laterza), 28-42.

Corsi P. (2001a): La scuola geologica pisana, in Storia dell'Università di Pisa, (Pisa), vol. 2, 889-927.

CoRsI, P. (2001b): La Geologia, in Storia dell'Università di Pisa, (Edizioni Plus, Università di Pisa), vol. 2, pt . 3, 894-895.
Corsi P. (2003): La Carta Geologica d'Italia: agli inizi di un lungo contenzioso, in Four Centuries of the Word Geology Ulisse Aldrovandi 1603 in Bologna, edited by G.B. VAI and W. CAVAZZA, (Bologna, Italy), 255-279.

DE Rossi, M.S. (1874): Scala convenzionale dei gradi d'intensità, in «quadri sinottici e cronologici dei fenomeni endogeni italiani», Bullettino del Vulcanismo italiano, 1, 21.

FERRARI, G. (2002): Census, filing and elaboration of scientific letters in the Earth sciences, in Nuncius, 17 (1), 307-320.

SGI (1882): Origine della Società, in Bollettino della Società Geologica Italiana, $\mathbf{1}$.

MusIANI, E. (2004): I caratteri di una strada: via Zamboni tra passato e presente, in Storia e Futuro, 4 (aprile 2004), (available on line at: www.storiaefuturo.com).

Sorbelli, A. (1928): Giovanni Capellini e il suo carteggio, in Archiginnasio, 23 (5-6), 245-267.

TABANELLI, C. (1989): La vita e le opere del naturalista Angelo Manzoni (1842-1895), in «In Rumagna». Aspetti della storia, della cultura e della tradizione, Anno 12/13, (Walberti, Lugo, Italy), 57-62.

VAI, G.B. (2003a): Giovanni Capellini and the origin of the International Geological Congress, in Four Centuries of the Word Geology Ulisse Aldrovandi 1603 in Bologna, edited by G.B. VAI and W. CAVAZZA, (Bologna), 301-315.

VAI, G.B. (2003b): A liberal diluvionism, in Four Centuries of the Word Geology Ulisse Aldrovandi 1603 in Bologna, edited by G.B. VAI and W. CAVAZZA, (Bologna), 221-250.

WIELL, S. (1999): The Congress of Anthropology and Archaeology in Copenhagen 1869 - behind the stage, in Antiquity, March 01. 
Vol52,6,2009New 2-12-2009 12:40 Pagina 678 